\title{
Experimental Investigation on the Material Removal of the Ultrasonic Vibration Assisted Abrasive Water Jet Machining Ceramics
}

\author{
Tao Wang, Rongguo Hou, and Zhe Lv \\ School of Mechanical Engineering, Shandong University of Technology, Zibo, China \\ Correspondence should be addressed to Rongguo Hou; hourongguo212@163.com
}

Received 24 January 2017; Revised 19 March 2017; Accepted 24 April 2017; Published 24 May 2017

Academic Editor: Charles C. Sorrell

Copyright ( 2017 Tao Wang et al. This is an open access article distributed under the Creative Commons Attribution License, which permits unrestricted use, distribution, and reproduction in any medium, provided the original work is properly cited.

The ultrasonic vibration activated in the abrasive water jet nozzle is used to enhance the capability of the abrasive water jet machinery. The experiment devices of the ultrasonic vibration assisted abrasive water jet are established; they are composed of the ultrasonic vibration producing device, the abrasive supplying device, the abrasive water jet nozzle, the water jet intensifier pump, and so on. And the effect of process parameters such as the vibration amplitude, the system working pressure, the stand-off, and the abrasive diameter on the ceramics material removal is studied. The experimental result indicates that the depth and the volume removal are increased when the ultrasonic vibration is added on abrasive water jet. With the increase of vibration amplitude, the depth and the volume of material removal are also increased. The other parameters of the ultrasonic vibration assisted abrasive water jet also have an important role in the improvement of ceramic material erosion efficiency.

\section{Introduction}

Abrasive water jet (AWJ) technology, as one of the fastest growing nonconventional machining processes, has been applied in many engineering fields such as aeronautics and mechanical manufacture $[1,2]$. The abrasive water jet has so many merits such as no heat deformation, high machining efficiency, high accuracy, and broad machining range. In order to improve the capability of the water jet machining, the pulsed water jet, which could cause a greater removal of target material by generating water-hammer effect, has been a research focus [3-5]. With an aim to produce high speed pulsed water jets, the mechanical methods including rotation, reciprocating, and wobbling have been successfully applied. However, the devices using these methods require tedious mechanical maintenance and their durability and reliability are in harsh working environments. Ultrasonic vibration has been used widely in abrasive water jet technology; for example, it is used to determine the vibration emission frequency when the abrasive particles impact the materials [ 6 , 7]. It is also used to produce the pulsed water jet; for example,
Vijay et al. [8] and Foldyna et al. [9, 10] have introduced a kind of high frequency pulsed water jet with the use of ultrasonic vibration activated in the nozzle; the jet's energy is pretty low. Lehocka et al. [11] have investigated the surface topography, morphology, and anisotropy of copper alloys created by pulsating water jet, and the results indicate that this new way of metal eroding can be used in the automotive and engineering industries in the future. Hloch et al. [12] have used the selective property of ultrasonic pulsating water jet for the disintegration of the interface created by bone cement as a potential technique for revision arthroplasty, and the results positively support an assumption that pulsating water jet has a potential to be a suitable technique for the quick and safe disintegration of bone cement during revision arthroplasty. Zelenak et al. [13] have tested the applicability of the shadowgraph technique combined with PIV processing algorithms to visualize water jet structure and analyze flow velocity field, and its results focus on the visualization of pulsating and continuous water jets, while there is little literature about experiment investigation on the material removal of the ultrasonic vibration assisted abrasive water jet 


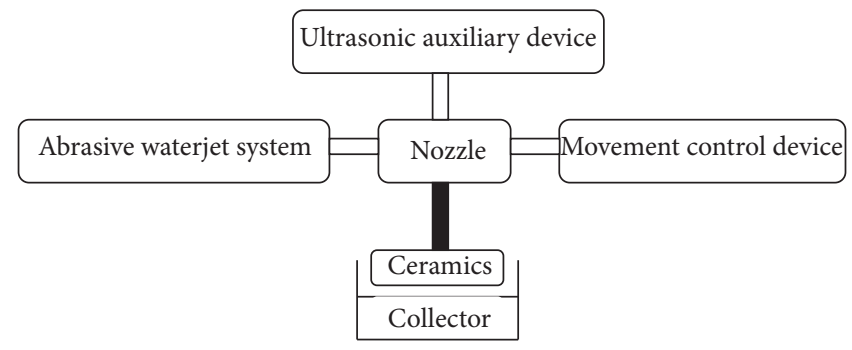

FIgURE 1: The sketch of experiment scheme.

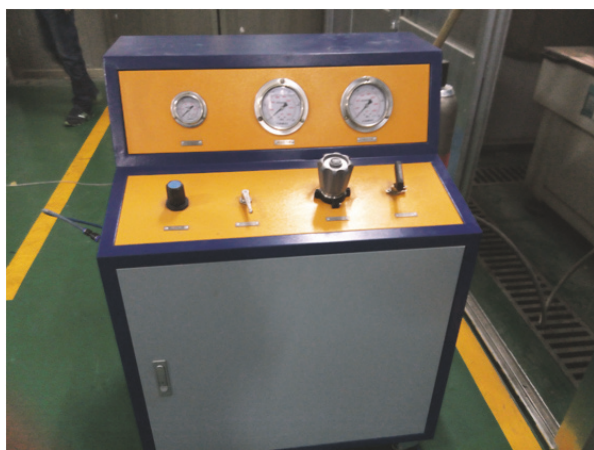

(a) The pneumohydraulic intensifier

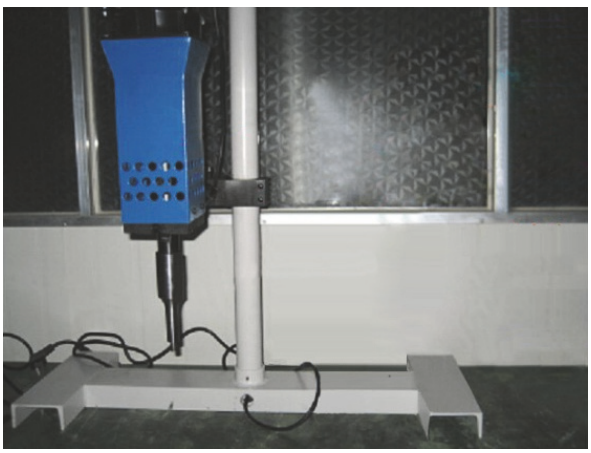

(b) The device of ultrasonic aided water jet

FIgURE 2: The device of ultrasonic vibration aided abrasive water jet.

impacting ceramics. With an aim to investigate the effect of the ultrasonic variations on the efficiency of abrasive water jet impacting the ceramics, a serial of experiments are carried out, and the effect of the vibration amplitude, the system working pressure, the distance of stand-off, and the abrasive diameter on the ceramics material removal is studied.

\section{Experimental Set-Up}

The experiment device of ultrasonic vibration assisted abrasive water jet, as Figure 1 shows, is composed of the ultrasonic auxiliary device, the abrasive water jet system including the abrasive water jet nozzle, the movement control device, the work piece (ceramics), the collector, and so on.

Among them, the ultrasonic auxiliary device, as is shown in Figure 2(b), can provide the vibration with a frequency of $20 \mathrm{KHz}$, and the amplitude is about $20 \mathrm{um}$, the vibration amplifier is used to change vibration aptitude, and it is connected with the abrasive nozzle by stud bolts; the abrasive water jet system, as is shown in Figure 2(a), can provide the water jet with a pressure within 0-70 Mpa, the working system pressure of water jet in this study is between 5 and $25 \mathrm{MPa}$, the value is pretty low because these experiments aim to study the micromachine the ceramics, and the ultrasonic vibration also helps to decrease the working pressure. The water jet nozzle diameter is $1 \mathrm{~mm}$. The stand-off is within $3-7 \mathrm{~mm}$ and the abrasive supply rate is $2.5 \mathrm{mg} / \mathrm{s}$.

The erosion surface morphology of experimental sample is observed and analyzed with the help of an instrument of 3D Laser Shape Measurement.
The alumina ceramics produced by National Engineering Laboratory of Ceramics are used as the work piece material and the purity of these alumina ceramics is $96 \%$; the mechanical property is shown in Table 1.

The green silicon carbide is used as abrasive, which is produced by a corundum manufacturing company named HeXing in ZhengZhou, and the mechanical property is shown in Table 2.

\section{Experimental Procedure}

The way of fixed-point erosion is used in this experiment, and each processing time is $8 \mathrm{~s}$. In this experiment, by changing the amplitude, the water jet pressure, the standoff, and the abrasive grain, the instrument of 3D Laser Shape Measurement will be used to observe and analyze the change law of area, shape, and depth in the erosion field; each sample point will suffer erosion for three times, and the average value will be used. The experiment parameters are shown in Table 3.

According to the method of single factor experiment, the designed experiment scheme is shown in Table 4.

\section{Experimental Result and Its Discussion}

Figure 3 shows the erosion surface morphology of alumina ceramics with and without the ultrasonic vibration assisted abrasive water jet. The erosion surface morphology of alumina ceramics is under the experimental condition that the size of abrasive grain is 320\#, the stand-off is $5 \mathrm{~mm}$, the supply rate of abrasive is $0.25 \mathrm{~g} / \mathrm{s}$, and the processing time is $8 \mathrm{~s}$. 
TABLE 1: The mechanical property of alumina ceramic [14].

\begin{tabular}{lcccc}
\hline Material & $\begin{array}{c}\text { Density } \\
\left(\mathrm{g} / \mathrm{cm}^{3}\right)\end{array}$ & $\begin{array}{c}\text { Vickers hardness } \\
(\mathrm{Gpa})\end{array}$ & $\begin{array}{c}\text { Bending strength } \\
(\mathrm{Mpa})\end{array}$ & $\begin{array}{c}\text { Fracture toughness } \\
\left(\mathrm{Mpa} \cdot \mathrm{m}^{1 / 2}\right)\end{array}$ \\
\hline $96 \%$ alumina & 3.7 & 20 & 320 & 3 \\
\hline
\end{tabular}

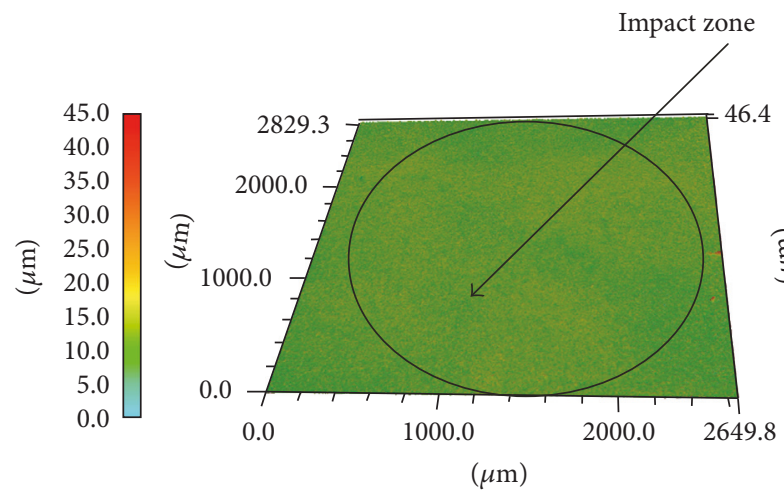

(a) Without the vibration (number 3 in Table 4)

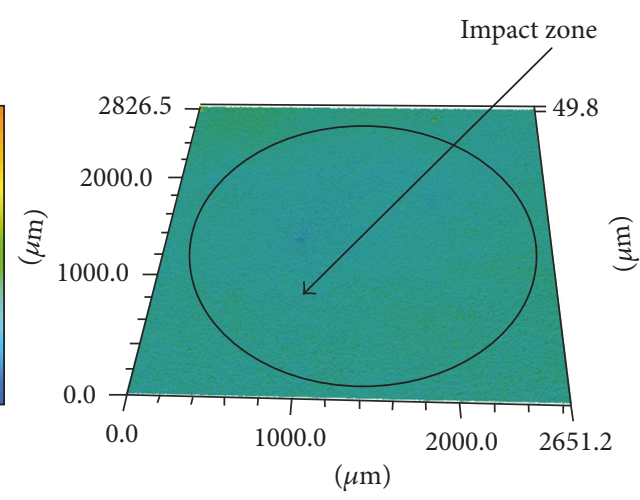

(b) With the vibration (number 4 in Table 4)

FIgURE 3: The erosion surface morphology of alumina ceramics.

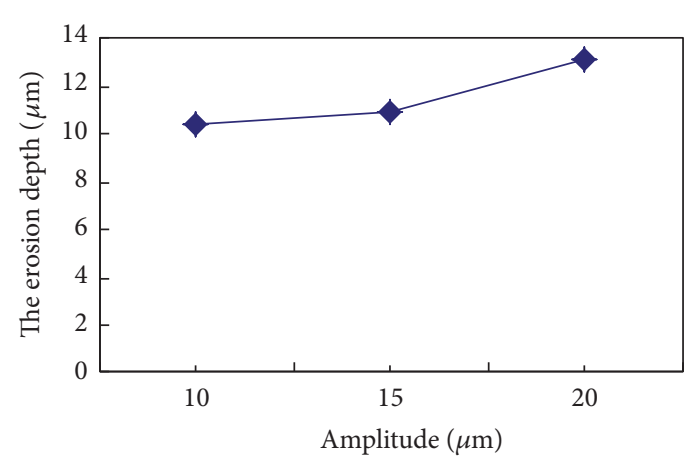

(a) The depth

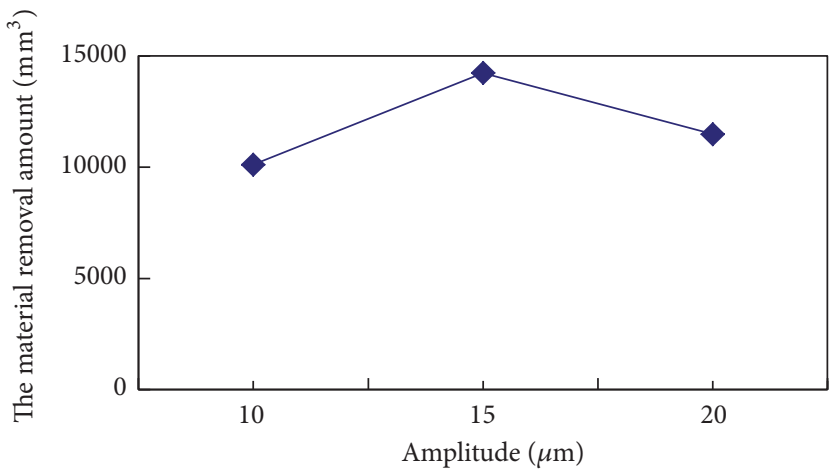

(b) The volume of material removal

FIgURE 4: The effect of amplitude on the depth and the material removal amount.

TABLE 2: The mechanical property of green silicon carbide [14].

\begin{tabular}{lcc}
\hline Material & Density $\left(\mathrm{g} / \mathrm{cm}^{3}\right)$ & Mosh hardness scale \\
\hline Green silicon carbide $(\mathrm{SiC})$ & 3.2 & 9.2 \\
\hline
\end{tabular}

As is shown in Figure 3 obviously, there are sporadic erosive pits in the erosion field without the ultrasonic vibration assisted abrasive water jet, and, for these pits, the depth and the volume of material removal are very small. In this experiment, the amount of erosive pits, the maximum depth of erosive pits and the volume of material removal increase simultaneously with the ultrasonic vibration assisted abrasive water jet. And the erosive area increases slightly with the ultrasonic vibration assisted abrasive water jet.

Figure 4 shows the effect of vibration amplitude on the depth of erosive pits and the volume of material removal. As is shown obviously, with the increase of amplitude, the depth of erosive pits and the volume of the material removal will increase firstly but decrease subsequently.

Figure 5 shows the effect of water jet pressure on the depth of erosive pits and the volume of material removal with different values of pressure, such as $5 \mathrm{MPa}, 10 \mathrm{MPa}$, $15 \mathrm{MPa}, 20 \mathrm{MPa}$, and $25 \mathrm{MPa}$. As is shown obviously, when the workpiece surface suffers vertical impact by abrasive water jet, the maximum depth will increase with the increase of water jet pressure, and that is because the lower the water jet pressure is, the smaller the normal component of the impact load becomes. And the surface roughness of initial workpiece is very large, and the volume of material removal is very small. However, the normal component of impact load, the depth, and the volume of material removal will increase simultaneously with the increase of water jet pressure.

Figure 6 shows the effect of stand-off on the depth and the volume of material removal. As is shown obviously, the stand-off has a small effect on the depth and the volume of material removal. 
TABLE 3: The experiment parameters.

\begin{tabular}{lcccc}
\hline $\begin{array}{l}\text { Abrasive } \\
(\text { mesh/\# })\end{array}$ & $\begin{array}{c}\text { Pressure } \\
(\mathrm{Mpa})\end{array}$ & $\begin{array}{c}\text { Amplitude } \\
(\mathrm{mm})\end{array}$ & $\begin{array}{c}\text { Stand-off } \\
(\mathrm{mm})\end{array}$ & Material \\
\hline $280,320,400$ & $5,10,15,20,25$ & $22,17,10$ & $3,5,7$ & Alumina ceramic, glass \\
\hline
\end{tabular}

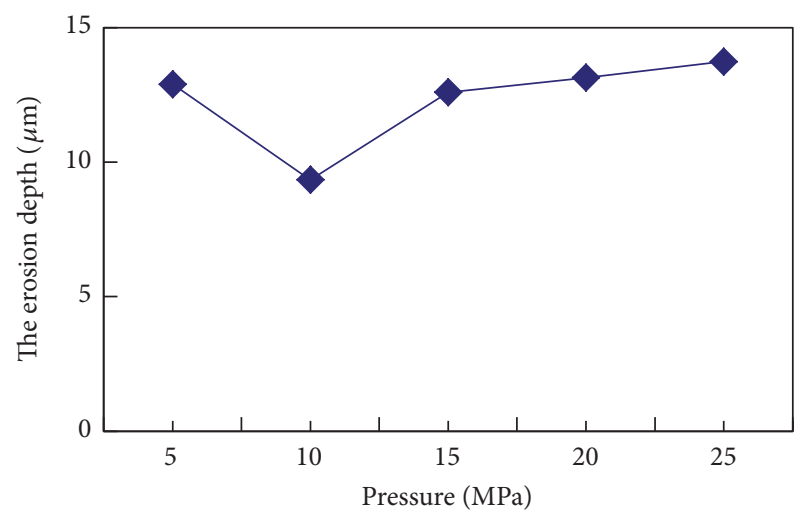

(a) The depth

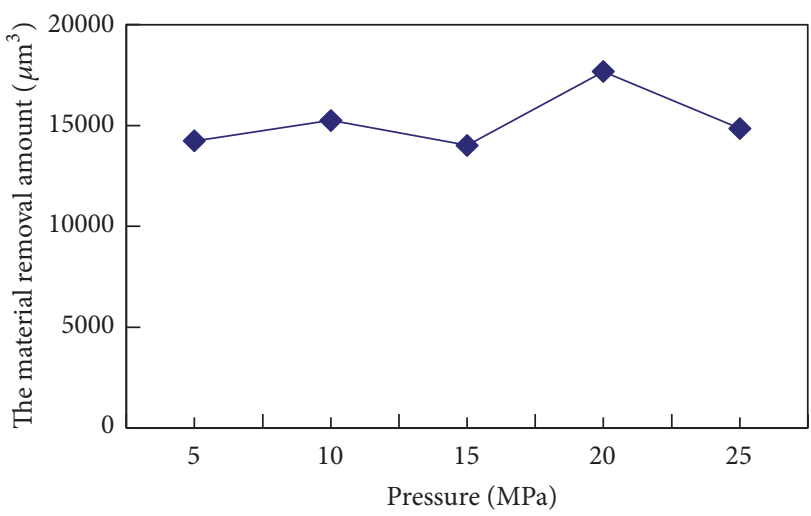

(b) The volume of material removal

FIGURE 5: The effect of water jet pressure on the depth and the volume of material removal.

TABLE 4: The experiment scheme.

\begin{tabular}{|c|c|c|c|c|}
\hline $\begin{array}{l}\text { Serial } \\
\text { number }\end{array}$ & $\begin{array}{c}\text { System pressure } \\
(\mathrm{Mpa})\end{array}$ & $\begin{array}{c}\text { Stand-off } \\
(\mathrm{mm})\end{array}$ & $\begin{array}{c}\text { Amplitude } \\
(\mathrm{mm})\end{array}$ & $\begin{array}{c}\text { Particle size } \\
(\mathrm{mesh} / \#)\end{array}$ \\
\hline 1 & 20 & 3 & 0 & 320 \\
\hline 2 & 20 & 3 & 22 & 320 \\
\hline 3 & 20 & 5 & 0 & 320 \\
\hline 4 & 20 & 5 & 22 & 320 \\
\hline 5 & 20 & 7 & 0 & 320 \\
\hline 6 & 20 & 7 & 22 & 320 \\
\hline 7 & 20 & 5 & 0 & 280 \\
\hline 8 & 20 & 5 & 22 & 280 \\
\hline 9 & 20 & 5 & 0 & 400 \\
\hline 10 & 20 & 5 & 22 & 400 \\
\hline 11 & 25 & 5 & 0 & 320 \\
\hline 12 & 25 & 5 & 22 & 320 \\
\hline 13 & 15 & 5 & 0 & 320 \\
\hline 14 & 15 & 5 & 22 & 320 \\
\hline 15 & 10 & 5 & 0 & 320 \\
\hline 16 & 10 & 5 & 22 & 320 \\
\hline 17 & 5 & 5 & 0 & 320 \\
\hline 18 & 5 & 5 & 22 & 320 \\
\hline 19 & 20 & 3 & 17 & 320 \\
\hline 20 & 20 & 5 & 17 & 320 \\
\hline 21 & 20 & 7 & 17 & 320 \\
\hline 22 & 20 & 5 & 17 & 280 \\
\hline 23 & 20 & 5 & 17 & 400 \\
\hline 24 & 25 & 5 & 17 & 320 \\
\hline 25 & 15 & 5 & 17 & 320 \\
\hline 26 & 10 & 5 & 17 & 320 \\
\hline 27 & 5 & 5 & 17 & 320 \\
\hline
\end{tabular}

TABLE 4: Continued.

\begin{tabular}{lcccc}
\hline $\begin{array}{l}\text { Serial } \\
\text { number }\end{array}$ & $\begin{array}{c}\text { System pressure } \\
(\mathrm{Mpa})\end{array}$ & $\begin{array}{c}\text { Stand-off } \\
(\mathrm{mm})\end{array}$ & $\begin{array}{c}\text { Amplitude } \\
(\mathrm{mm})\end{array}$ & $\begin{array}{c}\text { Particle size } \\
(\mathrm{mesh} / \#)\end{array}$ \\
\hline 28 & 20 & 3 & 10 & 320 \\
29 & 20 & 5 & 10 & 320 \\
30 & 20 & 7 & 10 & 320 \\
31 & 20 & 5 & 10 & 280 \\
32 & 20 & 5 & 10 & 400 \\
33 & 25 & 5 & 10 & 320 \\
34 & 15 & 5 & 10 & 320 \\
35 & 10 & 5 & 10 & 320 \\
\hline
\end{tabular}

Figure 7 shows the effect of abrasive grain on the erosion surface morphology with different values of abrasive, such as $280 \#, 320 \#$, and $400 \#$. As is shown obviously, the depth and the volume of material removal will increase firstly but decrease subsequently with the increase of abrasive. It indicates that, for the alumina ceramics, the abrasive has a small effect on the depth and the volume of material removal.

\section{Establishment of Experimental Model}

By analyzing the experimental result, it is easy to obtain the experimental model of depth and material removal amount for the ceramics which is machined by the ultrasonic vibration assisted abrasive water jet. The symbol of water jet pressure is $P_{s}$, the symbol of stand-off is $B$, the symbol of amplitude is $a$, and the symbol of abrasive is $M$; they all have a great effect on the surface morphology. Therefore, the above processing parameters which play an important role on the depth and the material removal amount will satisfy the relation, and the predicted model of depth and material 
TABLE 5: The coefficients of regression equation.

\begin{tabular}{lcccrr}
\hline Project & & \multicolumn{2}{c}{ Coefficient } & $w_{3}$ & $w_{4}$ \\
\hline$h_{1}$ & $w_{0}$ & $w_{1}$ & $w_{2}$ & 0.049 & -0.008 \\
$Q_{1}$ & 8.894 & 0.115 & 0.491 & 0.072 & 0.0077 \\
\hline
\end{tabular}

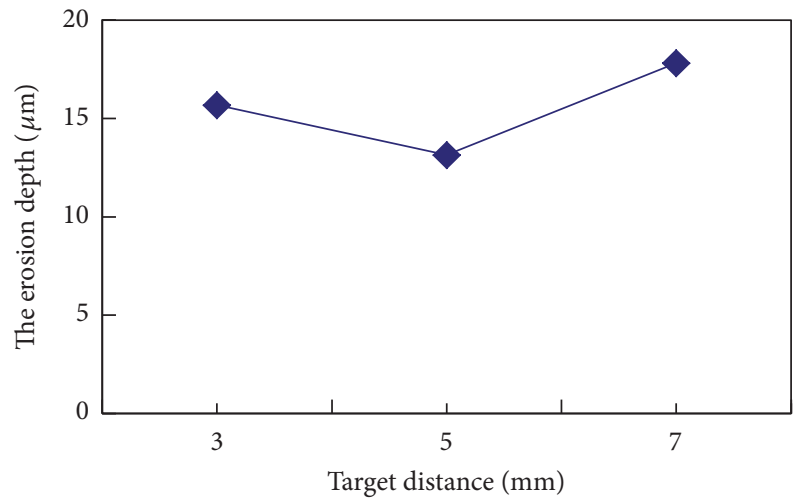

(a) The depth

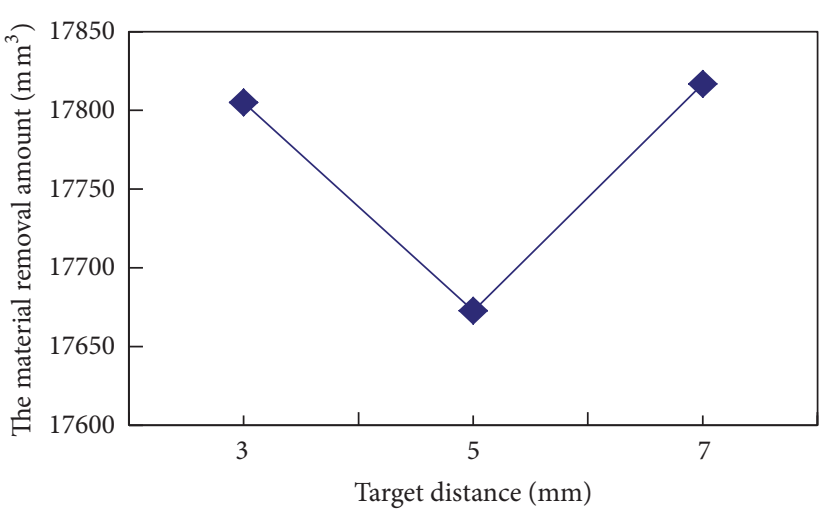

(b) The volume of material removal

FIGURE 6: The effect of stand-off on the depth and the volume of material removal.

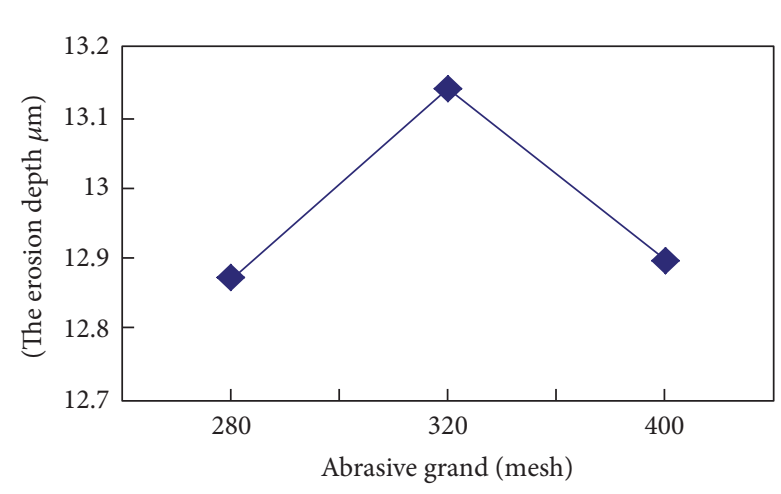

(a) The depth

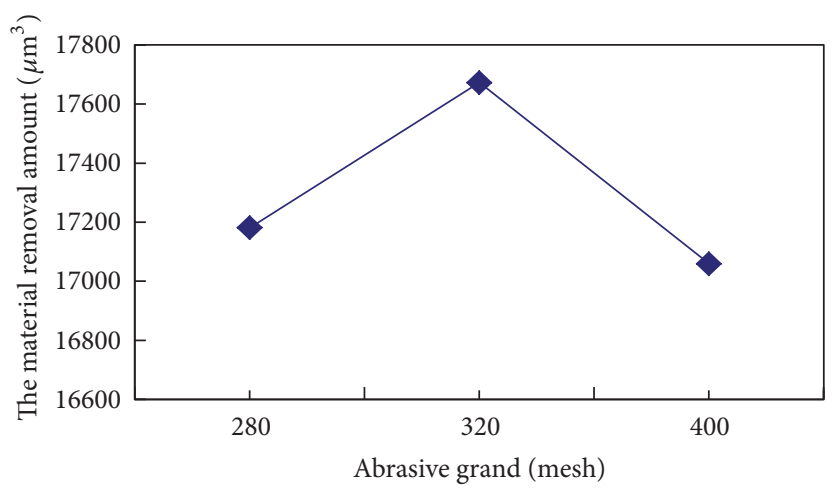

(b) The material removal amount

FIgURE 7: The influence of abrasive on the depth and the material removal amount.

removal amount for the alumina ceramics machined by the ultrasonic vibration assisted abrasive water jet is obtained:

$$
\begin{aligned}
h & =C P_{s}^{w_{1}} B^{w_{2}} a^{w_{3}} M^{w_{4}} \\
Q_{1} & =C P_{s}^{w_{1}} B^{w_{2}} a^{w_{3}} M^{w_{4}},
\end{aligned}
$$

where $h$ is depth $(\mathrm{mm}), Q_{1}$ is material removal amount $\left(\mathrm{mm}^{3}\right), C$ is coefficient which is related to the abrasive, and $w_{1}, w_{2}, w_{3}$, and $w_{4}$ are undetermined coefficients.

According to the experimental date, the MATLAB language is used to do the regression analysis $[15,16]$. The coefficients of the above regression equation are shown in Table 5.

Figure 8 shows the regression residual analysis. As is shown obviously, the regression coefficients of depth and material removal amount are within the confidence interval
(95\%), and it indicates that the above regression coefficients are reliable.

According to the comparison between all effects caused by different parameters, for the depth and the material removal amount, the stand-off and the water jet pressure have the biggest effect, the amplitude has a great effect, and the abrasive grain has a small effect.

\section{Conclusions}

This experimental study focuses on the ultrasonic vibration assisted abrasive water jet impacting the alumina ceramics. By measuring the surface morphology of alumina ceramics, the results indicate that the ultrasonic vibration improves the processing capability of abrasive water jet. Meanwhile, it also shows that both the depth and the material removal amount will increase when the ultrasonic vibration is applied. 


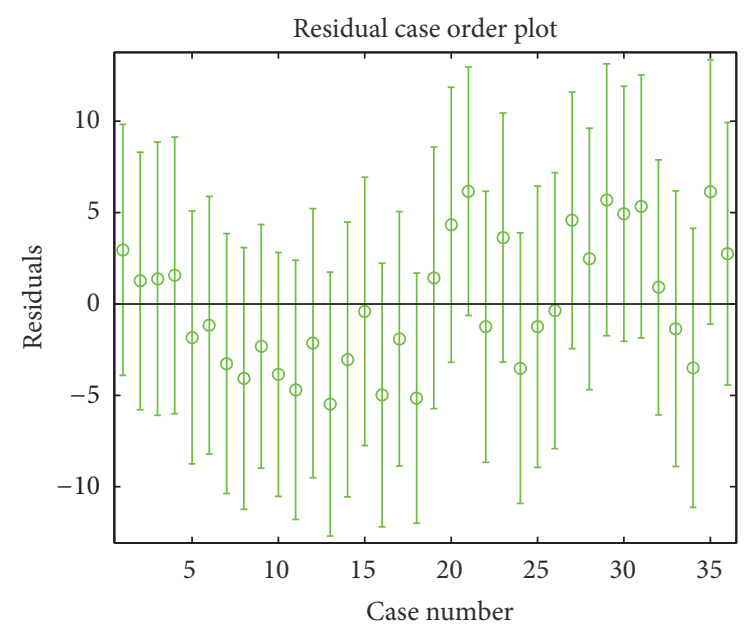

FIGURE 8: The analysis of residual.

A predicted model of depth and material removal amount is built. The results indicate that, for the depth and the material removal amount, the water jet pressure and the stand-off have the biggest effect, the amplitude has a great effect, and the abrasive grain has a small effect.

\section{Conflicts of Interest}

The authors declare that they have no conflicts of interest.

\section{Acknowledgments}

This work is financially supported by the National Natural Science Foundation of China (51405274) and Program for the Young Development of Shandong University of Technology.

\section{References}

[1] M. Hashish, "Pressure effects in Abrasive-WaterJet (AWJ) machining," Journal of Engineering Materials and Technology, vol. 111, no. 3, pp. 221-228, 1989.

[2] J. Wang, "Particle velocity models for ultra-high pressure abrasive waterjets," Journal of Materials Processing Technology, vol. 209, no. 9, pp. 4573-4577, 2009.

[3] G. L. Chahine, A. Kapahi, J.-K. Choi, and C.-T. Hsiao, "Modeling of surface cleaning by cavitation bubble dynamics and collapse," Ultrasonics Sonochemistry, vol. 29, pp. 528-549, 2016.

[4] G. L. Chahine, K. M. Kalumuck, and G. S. Frederick, "The use of self-resonating cavitating water jets for rock cutting," in Proceedings of the 8th American Water Jet Conference, 1995.

[5] S. Ghadi, K. Esmailpour, S. M. Hosseinalipour, and A. Mujumdar, "Experimental study of formation and development of coherent vortical structures in pulsed turbulent impinging jet," Experimental Thermal and Fluid Science, vol. 74, pp. 382-389, 2016.

[6] P. Hreha, A. Radvanská, S. Hloch, V. Peržel, G. Królczyk, and K. Monková, "Determination of vibration frequency depending on abrasive mass flow rate during abrasive water jet cutting," The International Journal of Advanced Manufacturing Technology, vol. 77, no. 1, pp. 763-774, 2015.
[7] V. Peržel, P. Hreha, S. Hloch, H. Tozan, and J. Valíček, "Vibration emission as a potential source of information for abrasive waterjet quality process control," The International Journal of Advanced Manufacturing Technology, vol. 61, no. 1, pp. 285-294, 2012.

[8] M. M. Vijay, J. Foldyna, and J. Remisz, "Ultrasonic modulation of high-speed waterjets," in Proceedings of the International Conference on Geomechanics, pp. 327-332, Netherlands, 1993.

[9] J. Foldyna, L. Sitek, J. Ščučka, P. Martinec, J. Valíček, and K. Páleníková, "Effects of pulsating water jet impact on aluminium surface," Journal of Materials Processing Technology, vol. 209, no. 20, pp. 6174-6180, 2009.

[10] J. Foldyna, L. Sitek, B. Švehla, and Š. Švehla, "Utilization of ultrasound to enhance high-speed water jet effects," Ultrasonics Sonochemistry, vol. 11, no. 3-4, pp. 131-137, 2004.

[11] D. Lehocka, J. Klich, J. Foldyna et al., "Copper alloys disintegration using pulsating water jet," Measurement, vol. 82, no. 3, pp. 375-383, 2016.

[12] S. Hloch, J. Foldyna, F. Pude et al., "Experimental in-vitro bone cements disintegration with ultrasonic pulsating water jet for revision arthroplasty," Journal of Tehnicki Vjesnik-Technical Gazette, vol. 22, no. 6, pp. 1609-1615, 2015.

[13] M. Zelenak, J. Foldyna, J. Scucka, S. Hloch, and Z. Riha, "Visualisation and measurement of high-speed pulsating and continuous water jets," Measurement, vol. 72, pp. 1-8, 2015.

[14] Z. W. Liu, Study on Removal Mechanism of Hard Brittle Materials and Premix Micro Abrasive Waterjet Polishing Technology, Shandong University, 2011.

[15] X. D. Yang, "Application of regression analysis method in ultra-precision machining surface roughness prediction," Value Engineering, vol. 33, no. 24, pp. 34-35, 2014.

[16] B. Zhao, Y. Wu, C. S. Liu, A. M. Gao, and X. S. Zhu, "The study on ductile removal mechanisms of ultrasonic vibration grinding nano- $\mathrm{ZrO}_{2}$ ceramics," Key Engineering Materials, vol. 304-305, pp. 171-175, 2006. 

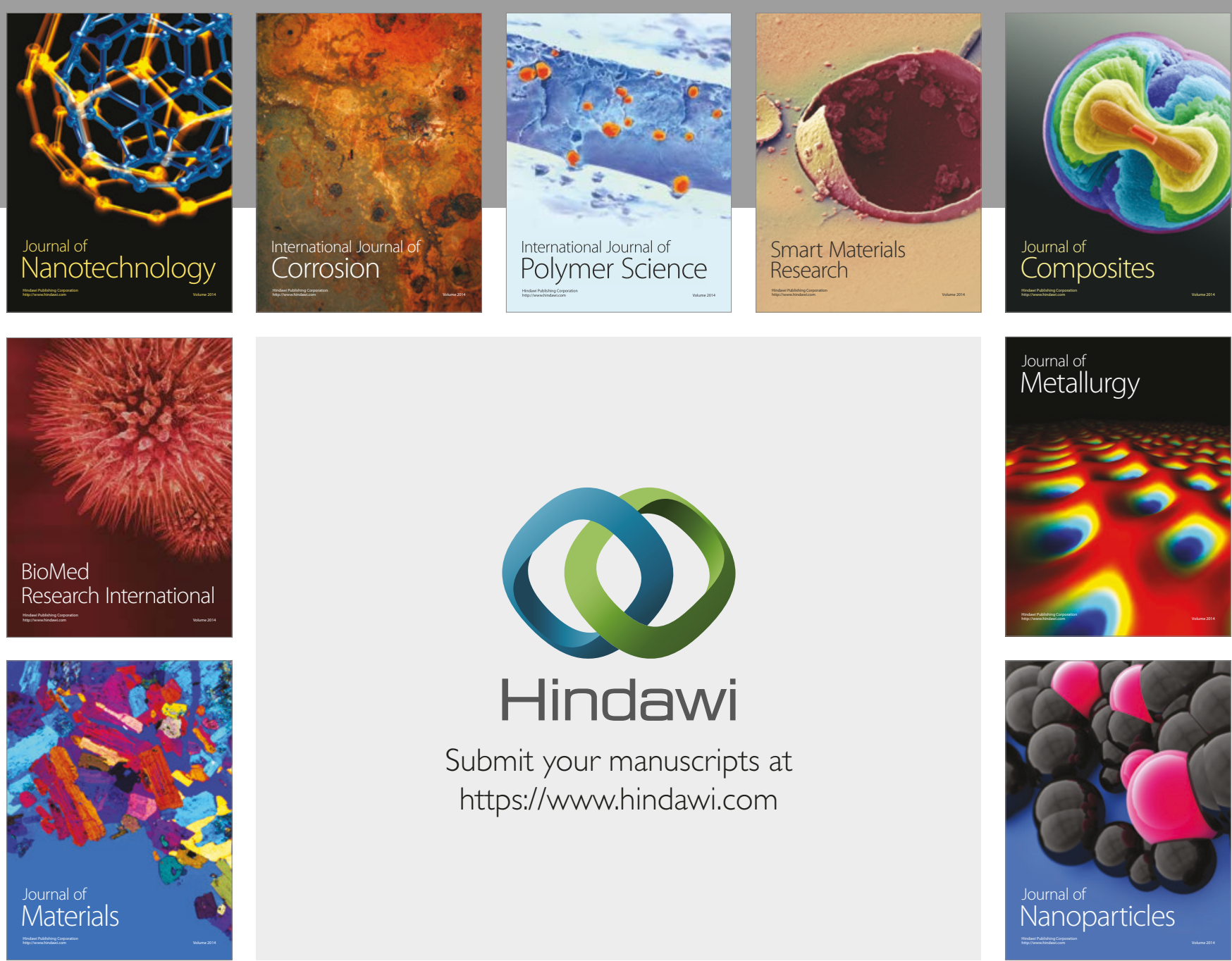

\section{Hindawi}

Submit your manuscripts at

https://www.hindawi.com
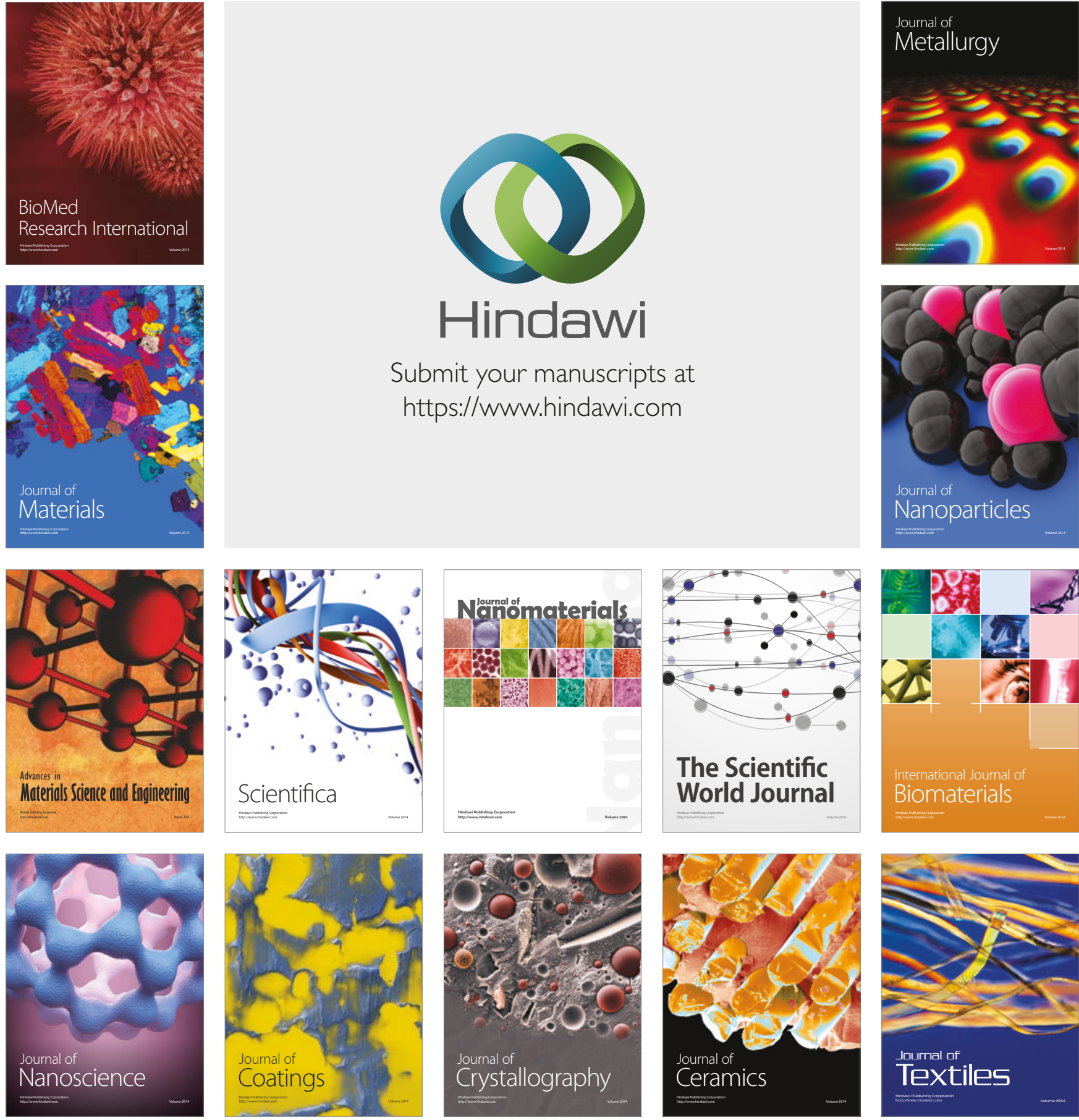

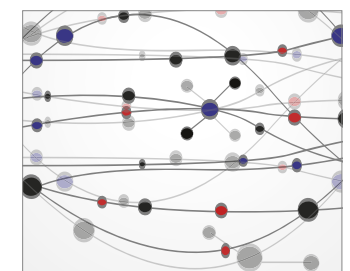

The Scientific World Journal
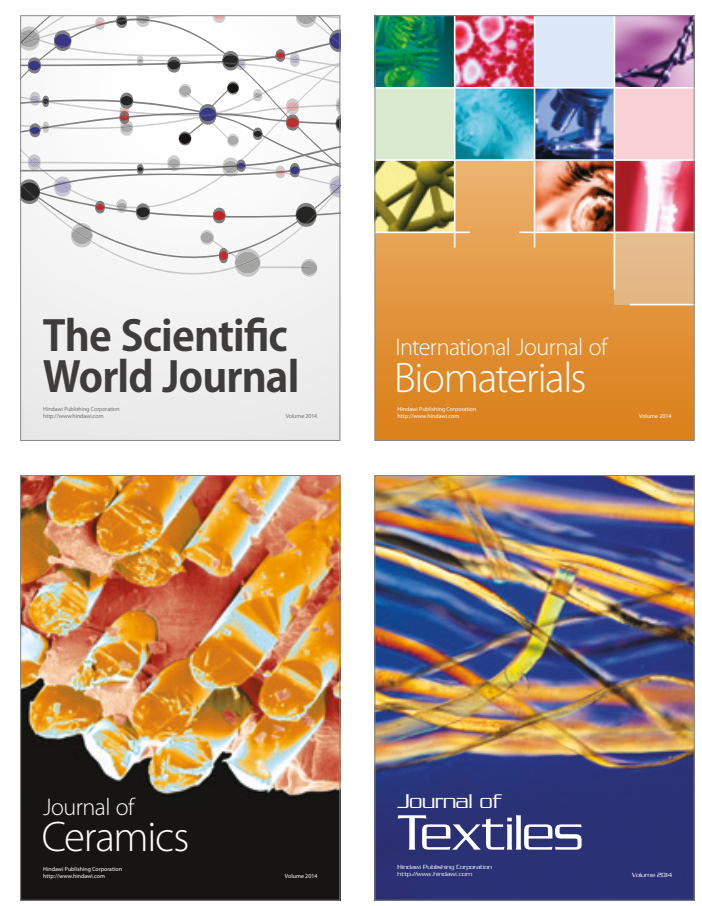